\title{
Pemberian Macam Konsorsium Bakteri Hasil Isolasi Tumbuhan Pantai pada Kangkung (Ipomoea reptans Poirs.)
}

\author{
DOI: $10.18196 /$ pt.2017.065.1-6
}

\author{
Umul Aiman*, Tantriati, Bambang Sriwijaya \\ Program Studi Agroteknologi Fakultas Agroindustri Universitas Mercu Buana Yogyakarta, \\ Jl. Wates Km. 10 Yogyakarta, Indonesia 55753, Telp. (0274) 7491807 Fax. (0274) 6498213 \\ *Corresponding author, email: umulaiman1966@gmail.com
}

\begin{abstract}
ABSTRAK
Konsorsium bakteri hasil isolasi rhizosfer (Rhizobacteria) tumbuhan dominan pantai berperan sebagai plant growth-promoting rhizobacteria (PGPR) yang dapat memacu pertumbuhan dan hasil tanaman. Tujuan dari penelitian ini adalah untuk mengetahui pengaruh macam konsosium bakteri terhadap pertumbuhan dan hasil kangkung. Penelitian telah dilaksanakan bulan Juni - September 2016 di Laboratorium Mikrobiologi, Laboratorium Agroindustri dan Laboratorium Tanah, Fakultas Agroindustri Universitas Mercu Buana Yogyakarta. Penelitian menggunakan percobaan lapangan faktor tunggal dengan 16 perlakuan dan 3 ulangan yang disusun dalam rancangan acak lengkap (RAL). Perlakuan dilakukan dengan perendaman benih kangkung dengan beragam konsorsium PGPR. Perlakuan yang dimaksud adalah perendaman dengan air atau tanpa PGPR, dan perendaman dengan K2, K9, K15, C7, K2 K9, K2K K15, K2C7, K9K15, K9C7, K15C7, K2K9K15, K2K9C7, K9K15C7, K2K15C7, dan K2K9K15C7. Bobot ekonomi kangkung dengan perendaman Konsorsium K2 K9K15C7 merupakan perlakuan yang terbaik dibandingkan perlakuan lain. Penggunaan dari beragam isolat tunggal K2, K9, K15, C7 maupun konsorsium rizobakteria K2K9, K2K15, K2C7, K9K15, K9C7, K15C7, K2K9K15, K2K9C7, K9K15C7, K2K15C7 mampu memberikan hasil kangkung yang lebih baik dibandingkan tanpa pemberian konsorsium.
\end{abstract}

Kata kunci: Konsorsium bakteria, PGPR, Kangkung, Rhizobacteria

\begin{abstract}
Bacteria consortium isolated from coastal plant was used as Plant Growth Promoting Rhizobacteria (PCPR) which can improve the growth and yield of plant. The purpose of this research was to understand the effects of various bacteria consortium application on the growth and yield of water spinach. The research was conducted on June-September 2016 in Microbiology Laboratory, Agroindustry Laboratory and Agriculture Land, University of Mercu Buana Yogyakarta. The study used a single factor experiment with 16 treatments and 3 blocks which arranged using completely randomized design (CRD). The treatment was desinged by soaking the water spinach seed on the various PGPR consorcium. All treatments were control (seed soaking on the water or without PGPR), the seed soaking on the various PGPR consorsium including K2, K9, K15, C7, K2K9, K2K 15, K2C7, K9K15, K9C7, K15C7, K2K K K15, K2K KCC7, K9K15C7, K2K15C7, and K2K9K15C7. The economic weight of water spinach which soaking on K2K9K15C7 consorcium was the best treatments compare to other treatments. Application of single isolate including K2, K9, K15, C7 and rhizobacteria consortium including K2K9, K2K15, K2C7, K9K15, K9C7, K15C7, K2K9K15, K2K9C7, K9K15C7, K2K15C7 can improved the yield of water spinach compare to the treatment without application of rhizobacteria. Keywords: Bacteria concortium, PGPR, Water spinach, Rhizobacteria
\end{abstract}

\section{PENDAHULUAN}

Jumlah penduduk Indonesia pada tahun 2015 mencapai 252.370 .792 juta jiwa dan terus mengalami peningkatan hingga $1,21 \%$ dari tahun ke tahun (Badan statistik Indonesia, 2015). Seiring dengan pertambahan jumlah penduduk maka kebutuhan bahan pangan pun meningkat. Salah satunya adalah komoditas sayuran sebagai sumber gizi bagi manusia, sehingga perlu diimbangi penambahan lahan pertanian. Sedangkan lahan pertanian yang subur semakin berkurang, sehingga diperlukan upaya memanfaatkan lahan yang belum dimanfaatkan secara maksimal. Indonesia memiliki lahan pasir pantai 1.060 .000 Ha (Putri, 2011), yang belum dikelola secara maksimal untuk peningkatan produktivitas.

Kangkung darat (Ipomoea reptans Poirs) merupakan tanaman yang potensial untuk dibudidayakan mengingat kandungan gizinya yang tinggi sebagai sumber vitamin, mineral dan serat makanan. Produksi kangkung Indonesia tahun 2013 sebanyak 308,477 ton dan tahun 2014 adalah 319.607 ton sedangkan konsumsi 
mencapai 1.02 juta ton (Kementerian Pertanian Direktorat Jenderal Hortikultura, 2015). Dikaitkan dengan ketahanan pangan maka dibutuhkan upaya peningkatan produksi pangan dengan laju yang tinggi dan berkelanjutan, sehingga dapat memenuhi kebutuhan yang belum tercukupi salah satunya dengan penggunaan Plant Growth Promoting Rhizobacteria (PGPR).

Banyak penelitian yang membuktikan bahwa mikrobia dari daerah rhizosfer dapat mendukung pertumbuhan tanaman. PGPR mampu meningkatan sintesis hormon seperti Indole acetic acid (IAA) atau giberalin (GA3) sebagai pemicu aktivitas enzim amilase yang berperan dalam perkecambahan (Gholami et al., 2009), menurunkan masa inkubasi, intensitas serangan TMV (Tobacco Mosaic Virus) dan menambah tinggi tanaman cabai rawit (A'yun et. al., 2013). Tanaman yang diberi konsorsium mikroorganisme memberikan hasil tanaman yang lebih baik dibandingkan tanpa pemberian konsorsium, pelarut fosfat memperluas jangkauan kemampuan tanaman untuk menyerap air maupun hara (Hemasempagam dan Selvaraj, 2011; Joseph, 2004; Husen et al., 2008).

Mikrobia yang tumbuh pada perakaran atau zona rizosfer dan yang mampu memacu pertumbuhan tanaman disebut PGPR (Husen et al., 2007). Mikrobia dari rhizozfer tumbuhan pantai diduga mampu meningkatkan pertumbuhan tanaman apabila diaplikasikan pada tanaman agar bertahan pada lahan marginal utamanya lahan pantai.

Dalam penelitian sebelumnya oleh Aiman et al. (2013) menyatakan bahwa dari tumbuhan dominan di pasir pantai Samas DIY, dapat diperoleh 13 isolat mikrobia yang potensial sebagai PGPR yang dibuktikan dengan kemampuanya menghasilkan IAA serta kemampuannya mengahsilkan Fosfat dengan dibuktikan adanya zona terang pada media Pikovkaya. Dari ke-13 mikrobia yang telah diisolasi, bakteri C7, K2, K9 dan K15, IAA yang dihasilkan relatif lebih tinggi dibandingkan isolat lainnya. IAA yang dihasilkan dari keempat bakteri tersebut berturut-turut sebesar 0,63 ppm untuk C7, 0,40 ppm untuk K2, dan K9 menghasilkan 0,60 ppm serta 0,59 ppm untuk isolat K15. Oleh karena itu, pada penelitian ini dilakukan uji penelitian lanjut untuk mengetahui kombinasi konsorsium PGPR terbaik dalam meningkatkan pertumbuhan dan hasil tanaman.

\section{BAHAN DAN METODE}

Bahan yang digunakan dalam penelitian ini adalah benih kangkung varietas Or-Nana, Media nutrisi cair (NB), Media nutrisi agar (NA) dengan penambahn agar sebanyak $2 \%$, Isolat bakteri: C7 ( hasil isolasi dari Cemara udang atau Casuarina equisetifolia) dan K2, K9, K15 (dari Katang-katang atau Ipomoea pascaprae), konsorsium PGPR terdiri dari: K2, K9, K15, C7, K2K9, K2K15, K2C7, K9K15, K9C7, K15C7, K2K9K15, K2K9C7, K9K15C7, K2K15C7, K2K9K15C7 dan tanpa konsorsium PGPR, pasir pantai, pupuk kandang sapi dan Polybag hitam ukuran $23 \mathrm{~cm} \times 13 \mathrm{~cm}$.

Metode penelitian yang digunakan adalah rancangan Acak Lengkap (RAL) dengan satu faktor. Faktor yang dimaksud adalah macam konsorsium bakteri untuk membuat PGPR. Semua perlakuan dilakukan 3 kali ulangan. Masing-masing perlakuan terdiri atas 5 tanaman sampel dan 2 tanaman cadangan. Perlakuan yang dimaksud adalah:

1. Benih kangkung direndam dalam air

2. Benih kangkung direndam dalam PGPR K2

3. Benih kangkung direndam dalam PGPR K9

4. Benih kangkung direndam dalam PGPR K15

5. Benih kangkung direndam dalam PGPR C7 
6. Benih kangkung direndam dalam PGPR K2K9

7. Benih kangkung direndam dalam PGPR K2K15

8. Benih kangkung direndam dalam PGPR $\mathrm{K} 2 \mathrm{C} 7$

9. Benih kangkung direndam dalam PGPR K9K15

10. Benih kangkung direndam dalam PGPR K9C7

11. Benih kangkung direndam dalam PGPR K15C7

12. Benih kangkung direndam dalam PGPR K2K9K15

13. Benih kangkung direndam dalam PGPR K2K9C7

14. Benih kangkung direndam dalam PGPR K9K15C7

15. Benih kangkung direndam dalam PGPR K2K15C7

16. Benih kangkung direndam dalam PGPR K2K9K15C7

Penelitian ini diawali dengan penyiapan konsorsium PGPR dengan kerapatan 16,7 X $10^{6}$. Isolat selanjutnya diinokulasikan pada media nutrient cair selama 5 hari hingga akhirnya larutan PGPR siap untuk digunakan. Aplikasi PGPR dengan dilakukan perendaman ada benih selama 2 jam dengan konsentrasi 1\%. Benih selanjutnya ditanam pada media pasir pantai Samas dan pupuk kandang dengan perbandingan 1:1. Tanaman dilakukan pemeliharaan yang dilakukan meliputi penyulaman, penyiraman, penyiangan, pengendalian hama dan penyakit.

Pengamatan dilakukan terhadap 5 tanaman sampel pada masing-masing perlakuan per ulangan. Pengamatan yang dilakukan meliputi tinggi tanaman, jumlah daun, bobot ekonomis, volume akar yang diukur dengan mengambil keseluruhan akar setelah dibersihkan dan memasukkannnya ke dalam gelas ukur yang telah berisi air, selanjutnya dihitung penambahan air yang terjadi, bobot segar brangkasan dengan melakukan penimbangan dengan timbangan Sartorius digital dengan ketelitian $10^{-4}$ dan bobot kering brangkasan dilakukan dengan pengeringan menggunakan oven sampai diperoleh bobot konstan.

Data yang diperoleh dianalisis menggunakan sidik ragam taraf 5\%. Apabila ada beda nyata, maka untuk mengetahui perlakuan yang berbeda nyata dilakukan uji lanjut dengan Duncan Multiple Range Test (DMRT) taraf 5\%.

\section{HASIL DAN PEMBAHASAN}

Hasil pengamatan dari variabel pertumbuhan dan hasil tanaman kangkung disajikan pada Tabel 1.

Tabel 1. Jumlah Daun Kangkung (helai) pada Umur 8 , 11, 14, 17, 20, dan 23 HST dengan Pemberian Macam Konsorsium yang Berbeda

\begin{tabular}{lllllll}
\hline \multirow{2}{*}{ Macam Konsorsium } & \multicolumn{5}{c}{ Rerata Jumlah Daun (helai) } \\
\cline { 2 - 7 } Tanpa PGPR & 8 HST & 11 HST & 14 HST & 17 HST & 20 HST & 23 HST \\
K2 & $2,00 a$ & $3,27 a$ & $4,47 a$ & $6,73 a$ & $10,27 a$ & $11,53 a$ \\
K9 & $2,00 a$ & $3,00 a$ & $4,93 a$ & $6,93 a$ & $10,20 a$ & $11,67 a$ \\
K15 & $2,00 a$ & $2,67 a$ & $4,27 a$ & $6,60 a$ & $9,87 a$ & $11,40 a$ \\
C7 & $2,00 a$ & $3,13 a$ & $4,87 a$ & $6,67 a$ & $9,80 a$ & $11,80 a$ \\
K2K9 & $2,00 a$ & $3,00 a$ & $4,73 a$ & $6,80 a$ & $10,13 a$ & $12,13 a$ \\
K2K15 & $2,00 a$ & $3,53 a$ & $5,20 a$ & $6,93 a$ & $10,40 a$ & $11,33 a$ \\
K2C7 & $2,00 a$ & $3,33 a$ & $5,07 a$ & $7,20 a$ & $10,13 a$ & $11,67 a$ \\
K9K15 & $2,00 a$ & $3,20 a$ & $5,00 a$ & $7,27 a$ & $10,00 a$ & $11,67 a$ \\
K9C7 & $2,00 a$ & $3,53 a$ & $5,27 a$ & $7,53 a$ & $10,13 a$ & $11,73 a$ \\
K15C7 & $2,00 a$ & $3,33 a$ & $4,67 a$ & $6,93 a$ & $9,60 a$ & $10,80 a$ \\
K2K9K15 & $2,00 a$ & $3,40 a$ & $5,00 a$ & $7,13 a$ & $10,47 a$ & $11,47 a$ \\
K2K9C7 & $2,00 a$ & $3,00 a$ & $4,33 a$ & $6,80 a$ & $9,93 a$ & $11,33 a$ \\
K9K15C7 & $2,00 a$ & $3,47 a$ & $5,33 a$ & $7,47 a$ & $10,53 a$ & $12,27 a$ \\
K2K15C7 & $1,60 a$ & $3,20 a$ & $4,53 a$ & $7,07 a$ & $10,47 a$ & $11,73 a$ \\
K2K9K15C7 & $2,00 a$ & $2,73 a$ & $4,40 a$ & $6,40 a$ & $9,73 a$ & $11,40 a$ \\
\hline & $2,00 a$ & $3,53 a$ & $5,07 a$ & $7,47 a$ & $10,47 a$ & $11,87 a$ \\
\hline
\end{tabular}

Keterangan: Nilai purata yang diikuti huruf yang sama dalam kolom yang sama tidak berbeda nyata menurut uji $\mathrm{F}$ taraf $5 \%$. 
Tabel 2. Tinggi Tanaman Kangkung (cm) Umur 5, 8, 11, 14, 17, 20, dan 23 HST dengan Pemberian Macam Konsorsium yang Berbeda

\begin{tabular}{|c|c|c|c|c|c|c|c|}
\hline \multirow{2}{*}{$\begin{array}{l}\text { Perlakuan } \\
\text { PGPR }\end{array}$} & \multicolumn{7}{|c|}{ Rerata Tinggi Tanaman $(\mathrm{cm})$} \\
\hline & $5 \mathrm{HST}$ & 8 HST & 11 HST & 14 HST & 17 HST & 20 HST & 23HST \\
\hline Tanpa PGPR & $0,49 a$ & $3,80 a$ & 6,93 a & $11,43 a$ & $15,23 \mathrm{a}$ & 22,87 a & $25,07 \mathrm{a}$ \\
\hline K2 & $0,59 a$ & $3,57 \mathrm{a}$ & $6,33 \mathrm{a}$ & $11,00 a$ & $14,93 \mathrm{a}$ & $22,00 a$ & $24,87 \mathrm{a}$ \\
\hline K9 & $0,53 \mathrm{a}$ & $3,70 a$ & $6,60 \mathrm{a}$ & 10,93 a & $15,13 \mathrm{a}$ & 22,07 a & $24,07 a$ \\
\hline K15 & $0,59 \mathrm{a}$ & $3,03 \mathrm{a}$ & 5,97 a & 10,13 a & $14,33 \mathrm{a}$ & $21,67 \mathrm{a}$ & $24,00 \mathrm{a}$ \\
\hline C7 & $0,58 a$ & $3,57 \mathrm{a}$ & $6,90 \mathrm{a}$ & $11,07 a$ & $15,50 \mathrm{a}$ & $21,67 a$ & 24,33 a \\
\hline K2К9 & $0,57 \mathrm{a}$ & $3,70 a$ & $6,93 \mathrm{a}$ & $11,43 a$ & $15,67 \mathrm{a}$ & $22,80 \mathrm{a}$ & $24,67 \mathrm{a}$ \\
\hline K2K15 & $0,74 a$ & 4,03 a & 7,17 a & 11,33 a & $15,87 \mathrm{a}$ & $23,27 a$ & $24,73 \mathrm{a}$ \\
\hline $\mathrm{K} 2 \mathrm{C} 7$ & $0,60 a$ & $3,87 \mathrm{a}$ & $7,37 a$ & $11,30 a$ & $16,13 \mathrm{a}$ & $22,40 a$ & $24,00 \mathrm{a}$ \\
\hline K9K15 & $0,49 a$ & $4,17 a$ & $7,23 \mathrm{a}$ & $11,60 a$ & $15,87 \mathrm{a}$ & $22,67 \mathrm{a}$ & $23,87 \mathrm{a}$ \\
\hline K9C7 & $0,51 \mathrm{a}$ & $4,20 \mathrm{a}$ & 7,37 a & $11,53 \mathrm{a}$ & $16,27 a$ & $22,53 \mathrm{a}$ & $24,07 \mathrm{a}$ \\
\hline K15C7 & $0,57 a$ & $4,17 \mathrm{a}$ & $7,80 \mathrm{a}$ & $12,07 \mathrm{a}$ & $16,27 a$ & $22,67 \mathrm{a}$ & $24,13 \mathrm{a}$ \\
\hline К2К9К15 & $0,47 a$ & $3,87 a$ & $6,87 \mathrm{a}$ & $10,73 \mathrm{a}$ & $14,93 \mathrm{a}$ & $21,33 \mathrm{a}$ & $23,07 a$ \\
\hline К2К9С7 & 0,46 a & $3,60 \mathrm{a}$ & $7,30 \mathrm{a}$ & $10,93 a$ & $15,00 \mathrm{a}$ & $21,20 a$ & $23,40 a$ \\
\hline К9К15C7 & $0,55 \mathrm{a}$ & $3,43 a$ & $6,30 \mathrm{a}$ & 10,53 a & $15,33 a$ & $22,00 \mathrm{a}$ & $24,87 a$ \\
\hline K2K15C7 & $0,49 a$ & $3,30 \mathrm{a}$ & $6,20 \mathrm{a}$ & $10,77 \mathrm{a}$ & $15,47 a$ & $21,67 \mathrm{a}$ & $23,87 a$ \\
\hline К2К9К15С7 & $0,49 a$ & $4,18 \mathrm{a}$ & $7,60 \mathrm{a}$ & 12,13 a & $16,53 \mathrm{a}$ & $23,67 a$ & $26,20 a$ \\
\hline
\end{tabular}

Keterangan: Nilai purata yang diikuti huruf yang sama dalam kolom yang sama tidak berbeda nyata menurut uji $\mathrm{F}$ taraf $5 \%$.

Tabel 3. Bobot Ekonomis (g), Volume akar (ml), Bobot Segar Brangkasan (g) dan Bobot Kering Brangkasan (g) dengan Pemberian Macam Konsorsium yang Berbeda

\begin{tabular}{|c|c|c|c|c|}
\hline \multirow[b]{2}{*}{ Macam Konsorsium } & \multicolumn{4}{|c|}{ Rerata Jumlah Daun (helai) } \\
\hline & $\begin{array}{c}\text { Bobot } \\
\text { Ekonomis (g) }\end{array}$ & $\begin{array}{c}\text { Volume } \\
\text { Akar (ml) }\end{array}$ & $\begin{array}{c}\text { Bobot Segar } \\
\text { Brangkasan (g) }\end{array}$ & $\begin{array}{c}\text { Bobot Kering } \\
\text { Brangkasan }(\mathrm{g})\end{array}$ \\
\hline Tanpa PGPR & $5,20 \mathrm{~b}$ & $10,67 a$ & $20,47 a$ & $1,52 \mathrm{a}$ \\
\hline K2 & $11,77 \mathrm{a}$ & $11,87 a$ & $26,29 a$ & 1,98 a \\
\hline K9 & 8,88 a & $10,87 \mathrm{a}$ & $21,70 \mathrm{a}$ & $1,98 \mathrm{a}$ \\
\hline K15 & 9,62 a & $12,80 \mathrm{a}$ & 25,17 a & $2,83 a$ \\
\hline $\mathrm{C7}$ & 9,67 a & $12,53 \mathrm{a}$ & $24,66 a$ & $2,08 \mathrm{a}$ \\
\hline K2K9 & 9,83 a & $14,20 \mathrm{a}$ & $26,33 \mathrm{a}$ & $2,72 \mathrm{a}$ \\
\hline K2K15 & $10,31 \mathrm{a}$ & $14,60 \mathrm{a}$ & $27,77 \mathrm{a}$ & $3,06 \mathrm{a}$ \\
\hline $\mathrm{K} 2 \mathrm{C7}$ & $11,20 \mathrm{a}$ & $14,27 \mathrm{a}$ & $27,90 \mathrm{a}$ & $2,23 \mathrm{a}$ \\
\hline K9K15 & 11,07 a & $13,53 \mathrm{a}$ & $25,72 \mathrm{a}$ & $2,50 a$ \\
\hline K9C7 & $12,25 \mathrm{a}$ & $13,60 \mathrm{a}$ & $28,60 \mathrm{a}$ & $2,97 a$ \\
\hline K15C7 & $11,69 a$ & $14,27 a$ & $28,39 a$ & $2,88 \mathrm{a}$ \\
\hline K2K9K15 & $10,93 \mathrm{a}$ & $14,47 \mathrm{a}$ & $26,91 \mathrm{a}$ & $2,52 \mathrm{a}$ \\
\hline K2K9C7 & $11,27 \mathrm{a}$ & $12,53 \mathrm{a}$ & $28,56 \mathrm{a}$ & $2,60 \mathrm{a}$ \\
\hline K9K15C7 & $11,40 a$ & $12,67 \mathrm{a}$ & $28,83 \mathrm{a}$ & $2,79 a$ \\
\hline K2K15C7 & $11,60 \mathrm{a}$ & $13,47 a$ & $28,04 \mathrm{a}$ & 1,87 a \\
\hline К2К9К15С7 & $12,13 \mathrm{a}$ & $14,80 \mathrm{a}$ & $28,73 \mathrm{a}$ & $3,06 \mathrm{a}$ \\
\hline
\end{tabular}

Keterangan: Nilai purata yang diikuti huruf yang sama dalam kolom yang sama tidak berbeda nyata menurut uji $\mathrm{F}$ taraf $5 \%$
Tinggi tanaman kangkung umur 5, 8, 11, 14, 17, 20, dan 23 HST dengan pemberian beragam macam isolat tunggal terdiri $\mathrm{K} 2, \mathrm{~K} 9, \mathrm{~K} 15$, $\mathrm{C} 7$ dan konsosium yang terdiri $\mathrm{K} 2 \mathrm{~K} 9, \mathrm{~K} 2 \mathrm{~K} 15$, K2C7, K9K15, K9C7, K2K9K15, K2K9C7 dan K2K15C7 serta K2K9K15C7 menunjukkan tinggi yang tidak berbeda pada semua perlakukan termasuk yang tanpa pemberian PGPR (Tabel 1). Pada jumlah daunpun juga tidak terjadi perbedaan (Tabel 2), sedangkan bobot ekonomis pada pemberian macam konsorsium PGPR menunjukkan bobot yang lebih besar dibandingkan tanpa PGPR (Table 3), volume akar, bobot segar brangksan dan bobot kering brangkasan semuanya tidak menunjukkan perbedaan (Tabel 4). Pada Tabel 1, 2 dan 3 pemberian macam konsorsium $\mathrm{K} 2 \mathrm{~K} 9 \mathrm{~K} 15 \mathrm{C} 7$ cenderung menunjukkan hasil yang lebih tinggi dibandingkan perlakuan lainnya.

Plant growth promoting rhizobacteria (PGPR) memiliki peran sebagai biostimulant, bioprotectan maupun biofertilizer (Febriyanti et al., 2015). Fungsi biostimulant ini diakibatkan oleh adanya produksi salah satu hormon yaitu IAA (Indole acetic acid) (Aiman et al., 2013) sebagai senyawa alami yang berperan dalam pembelahan sel dan mendorong pembentukan akar adventif. Namun, meskipun auksin berada dalam jumlah yang banyak, di tahap awal perkecambahan IAA belum terlalu banyak dibutuhkan. Sehingga pemberian macam konsorsium PGPR belum begitu memberikan pengaruh yang signifikan pada fase kecambah.

Pertumbuhan tanaman juga dipengaruhi oleh faktor internal dan eksternal. Faktor internal berhubungan dengan perakaran tanaman yang banyak dipengaruhi oleh faktor genetik. Didukung oleh Septian et al. (2015) tanaman kangkung merupakan tanaman yang dipanen 
pada fase vegetatif dan memiliki perakaran yang cukup baik dalam penyerapan unsur hara. Sedangkan faktor eksternal menjadi faktor pendukung pertumbuhan seperti suhu, kelembaban, serangan hama penyakit, curah hujan dan cahaya matahari. Fotosintesis akan berjalan dengan baik melalui pemanfaatan energi cahaya matahari. Hasil dari proses fotosintesis berupa energi akan dimanfaatkan tanaman untuk membentuk sel baru yang juga berpengaruh pada pertumbuhan tinggi tanaman kangkung.

PGPR mampu menghasilkan hormon auksin yang juga berperan untuk menjaga tingkat kesegaran dari tanaman. Lebih lanjut A'yun (2013) menyebutkan bahwa Mekanisme secara langsung yang dilakukan oleh PGPR yaitu dengan cara mensintesis metabolit misalnya senyawa yang merangsang pembentukan fitohormon seperti indole acetic acid (IAA), atau dengan meningkatkan pengambilan nutrisi tanaman. IAA merupakan salah satu hormon pertumbuhan tanaman yang sangat penting. IAA merupakan bentuk aktif dari hormon auksin yang dijumpai pada tanaman dan berperan meningkatkan kualitas hasil panen.

Penambahan PGPR juga berperan dalam peningkatan kandungan kloroplas sehingga terjadi peningkatan fotosintesis per luasan daun. Hal ini didukung oleh Phabiola et al. (2012) yang menyatakan bahwa perlakuan PGPR dapat meningkatkan klorofil daun dari 23,81\% menjadi $28,22 \%$ pada 15 hari setelah pemberian formula PGPR. Terjadinya peningkatan ini diakibatkan oleh adanya aktifitas ACC-Deaminase pada PGPR memperlambat proses degradasi klorofil atau meningkatkan fotosintesis per luasan daun dibandingkan tanpa pemberian PGPR. Sebagai biofertilizer bagi tanaman, PGPR merupakan pupuk hayati mampu menyediakan unsur hara bagi pertumbuhan tanaman, sehingga tanaman mampu tumbuh dengan optimal dan memiliki ketahanan terhadap serangan hama, penyakit maupun cekaman yang berasal dari lingkungan.

\section{SIMPULAN}

Dari penelitian yang telah dilakukan dapat disimpulkan sebagai berikut:

1. Pemberian macam isolat tunggal rizobakteri $\mathrm{K} 2, \mathrm{~K} 9, \mathrm{~K} 15, \mathrm{C} 7$ dan konsorsium rhizobakteri K2K9, K2K15, K2C7, K9K15, K9C7, K15C7, K2K9K15, K2K9C7, K9K15C7, K2K15C7, K2K9K15C7 menghasilkan pertumbuhan dan hasil kangkung lebih baik dibandingkan dengan tanpa pemberian rhizobakteria tunggal maupun konsorsium.

2. Perlakuan pemberian macam bakteri konsorsium K2K9K15C7 menghasilkan bobot ekonomis lebih baik dibanding tanpa pemberian macam konsorsium.

\section{DAFTAR PUSTAKA}

Aiman, U., Sriwijaya B. dan Swasono D.H. 2013. Eksplorasi Mikrobia Rhizosfer Tumbuhan Pantai Potensial Sebagai Pemacu Pertumbuhan Tanaman.Prosiding Seminar Nasional UNS. Akselerasi Pembangunan pertanian menuju kemandirian pangan dan enerhi tahun 2013.

A'yun, K Q., Tutung H dan Mintarto M. 2013.Pengaruh Penggunaan PGPR Plant Growth Promoting Rhizobacteria) Terhadap intensitas TMV (Tobacco Mosaic Virus), Pertumbuhan, dan Produksi Pada Tanaman Cabai Rawit (Capsicum frutescens L.). Jurnal Hama Penyakit Tanaman: I (1): 47-55.

Badan Statistik Indonesia. 2015a. Hasil Sensus Penduduk Indonesia (online) http://www.bps.go.id/aboutus.php?sp=0, diakses 13 Januari 2016.

Kementerin Pertanian Direktorat Jenderal Hortikultura. 2015. Statistik Produksi Hortikultura, 2015. Departemen Pertanian. http://www.hortikultura.deptan.go.id/index.php?option=com_ content\&task=view\&id=129\&ltemid=164. [diakses 30 Mei 2016].

Febriyanti, L.E., Martosudiro, M., dan Hadiastono, T., 2015.Pengaruh Plant Growth Promoting Rhizobacteria (Рgpr) Terhadap Infeksi Peanut Stripe Virus (Pstv), Pertumbuhan DanProduksi Tanaman Kacang Tanah (Arachis hypogaea L.) Varietas Gajah. Jurnal Hama dan Penyakit Tumbuhan.III (1): 84-92.

Gholami, A., S. Shahsavani, and S. Nezarat. 2009. The effect of 
plant growth promoting rhizobacteria (PGPR) on germination, seedling growth and yield of maize. World Academy of Science, Engineering and Technology XLIX. Page:19-24.

Hemahenpagam N. And Selvaraj T. (2011). Effect of arbuscular mycorrhizal (AM) fungus and plant growth promoting microorganisms(PGPR's) on medicinal plant Solanum viarum seedling. J. Environ. Biology. XXXII: 579-583.

Husen, E., Rasti Sarasati, dan Ratih Dewi Hastuti, 2007. Rizobakteri Pemacu Tumbuh Tanaman, Http://balittanah.litbang. deptan.go.id/, 16 Juli 2015.

Husen, E., Rasti Sarasati, dan Ratih Dewi Hastuti, 2008. Rizobakteri Pemacu Tumbuh Tanaman. www.nuance.com (diakses 15 Mei 2016).

Joseph, W. 2004. Induced systemic resistance and promotion of plant growth by Bacillus spp. Phytopathology :1259-1266.

Phabiola, Trisna Agung. Dan Khalimi, K. 2012. Pengaruh Aplikasi Formula Pantoea agglomerans Terhadap Aktivitas Antioksidan dan Kandungan Klorofil Daun Tanaman Strowberi. Jurnal Agrotop II (2): 125- 131.

Putri, F.2011. Bertani Di Lahan Pasir. www.bbpp-Lembang .info (diakses, 7 Februari, 2017).

Septian, N.A.W., N. Aini, dan N. Herlina. 2015. Pengaruh Pemberian Pupuk Organik Terhadap Pertumbuhan dan Hasil Tanaman Jagung Manis (Zea mays Saccharata) Pada Tumpangsari dengan Tanaman Kangkung (Ipomea reptans). Fakultas Pertanian, Universitas Brawijaya. Jurnal Produksi Tanaman, III (2): $141-14$. 